\title{
Надія ШОСТАКІВСЬКА
}

\author{
Тернопільський національний технічний університет \\ імені Івана Пулюя, Тернопіль, Україна
}

\section{ФОРМУВАННЯ МЕХАНІЗМУ ПРОТИДІЇ ТІНЬОВОМУ СЕКТОРУ УКРАЇНСЬКОЇ ЕКОНОМІКИ}

\begin{abstract}
Резюме. Проблема тіньової економіки є актуальною на рівні начіональної економіки краӥни. 3 а останні роки поліпшення соціально-економічного рівня життя населення знизило увагу до означеної проблеми. Але під час иього зберігся негативний вплив означеного сегмента економіки на національне господарство в досить великих розмірах. Нині не розроблено комплексного підходу для усунення всіх наявних наслідків функціонування тіньового сектора, але існують ефективні способи боротьби лише з окремими проявами вищезазначеного сегмента. У процесі всі вони не враховують ні регіональних, ні національних особливостей. Зменшення обсягу тіньового обороту є першочерговим завданням для державної політики кожної краӥни, але в процесі необхідно ретельно підбирати засоби його зниження.

Необхідно вибірково знаходити заходи регулювання діяльності суб'єктів господарювання. Для вирішення проблеми тіньової економіки необхідно проаналізувати взаємний вплив тіньової та офіційної економіки, на всі сфери суспільного життя, розробити методики оиінювання масштабності тіньового сегмента по всіх видах економічної діяльності, ефективні способи перенесення економічних $і$ фінансових ресурсів у легальну економіку.

Комплексний підхід до розроблення науково обгрунтованих заходів економічного й адміністративного характеру в кінцевому підсумку призведе до зменшення частки тіньового сектора в національній економічі і сприятиме стабільному розвитку економіки краӥни. Існує три основні підходи до формування механізму протидії держави тіньової економіки: організаційний, управлінський та організаційно-управлінський підходи.
\end{abstract}

Ключові слова: тіньова економіка, державне регулювання, механізм протидї тіньовій економіці, організаційно-управлінський підхід до тіньової економіки.

\section{Nadiya SHOSTAKIVSKA}

\section{Ternopil Ivan Pul’uj National Technical University, Ternopil, Ukraine}

\section{FORMATION OF THE MECHANISM OF ANTI-MEDIA TO THE UNDERGROUND SECTOR OF UKRAINIAN ECONOMY}

\footnotetext{
Sammary. The problem of underground economy is actual at the level of national economy of the country. For the last few years the improvement of socio-economic standard of living of population reduced attention to the noted problem, but during the process negative influence of the noted segment of economy was preserved on a national economy in largenesses enough. Presently it is not developed complex approach for the removal of all present consequences of functioning of underground sector, but there are effective methods of coping only with the separate displays of afore-mentioned segment, but within the process all of them do not take into account either regional or national, features.

Diminishing of volume of underground turnover is a near-term task, for the public policy of every country, but in this process it is necessary carefully to pick up facilities of its decline. It is necessary preferentially to find the measures of adjusting of activity of subjects of menage. To solve the problem of underground economy it is necessary to analyse the cross-coupling of unofficial and official economy, in all spheres of public life, to develop the methods of estimation of scale of shadow segment in all types of economic activity, effective methods of transference of economic and financial resources in a legal economy.

The complex approach to the development of the scientifically grounded measures of economic and administrative character will eventually result in diminishing of part of a unofficial sector in a national economy
} 
and will assist stable development of country's economy. There are three basic approaches to forming the mechanism of counteraction of the state of underground economy: organizational, administrative and organizationally administrative approach.

Key words: underground economy, government control, mechanism of counteraction a underground economy, organizationally administrative approach to underground economy.

Постановка проблеми. Загальновідомо, що тіньова економіка $є$ складовою економіки, яка зазнає значних змін протягом усього періоду розвитку будь-якої держави. При цьому тіньова економіка використовує механізми, аналогічні офіційній економіці Вони включають правила ціноутворення, способи реалізації контрактів, комплекс професій, механізми формування конкурентного середовища, що негативно позначається на податковій складовій доходної частини консолідованого бюджету. Поряд 3 цим тіньова активність стає значною перешкодою розвитку інвестиційної діяльності й певною мірою «консервує» сучасний складний стан економіки.

Сучасна Україна потребує побудови економічно вигідних взаємовідносин держави, бізнесу і кінцевого споживача. При цьому процес розвитку й удосконалення системи економічних інтересів потребує подальшого наукового розроблення та обгрунтування. При цьому важливо, щоб система інтересів векторно збігалася 3 принципами забезпечення економічної безпеки в рамках неналежного виконання існуючих законів і не створювала конфліктних ситуацій у різних соціальних верствах суспільства. Теоретична й практична важливість даної проблеми дозволяють віднести іiі до затребуваних напрямків розвитку економічної теорії.

Аналіз останніх досліджень і публікацій. Огляд наукових досліджень свідчить, що існуючий спектр використовуваних науково-методичних підходів, моделей, методик, експертно-аналітичних методів, інформаційних технологій може бути взятий за базовий і під час дослідження доопрацьований та використаний шляхом формування механізму протидії тіньовій економіці. Разом 3 тим, наукові роботи А.Г. Алтуняна, А.В. Вахрамєєва, Н.А. Журавльової, В.І. Лісової, А.А. Кукліна, А.І. Попова, Ф.Ф. Рибакова, В.К. Сенчагова, С.П. Федосової, Ю.В. Яковця, С. Деварейджена, К. Джонса, М. Ромера, М. Морріса, М. Ньюмена, Е. Де Сото зробили значний внесок у розвиток теорії та практики забезпечення економічної безпеки в сучасній Україні та рубежем.

Вивченню процесів, що відбуваються в тіньовій економіці, присвячені роботи таких авторів, як Г.А. Агарков, В.І. Авдійскій, М. Завельский, В.В. Колесніков, Н.І. Іванова, А.Г. Корчагін, Ф. Конт, М.К. Кадішева, Ю.В. Латів, Ю.Н. Лебедєва, I.М. Соловйов, Е.В. Рогожина, Т.В. Фетисова, І. Ейрлі.

Генезису тіньових економічних відносин, дослідженню кримінальних явищ у сучасному українському суспільстві та їх впливу на економіку й управління присвячені наукові праці С.М. Ечмакова, С.С. Металеві, С.К. Осипова, І.С. Нафикова, Е.В. Рогожин, Н.Д. Еріашвілі.

На думку автора, при розробленні та обгрунтуванні механізмів протидії тіньовому сектору української економіки вплинули роботи Г.А. Агаркова, І.Н. Барціц, В.Н. Бикова, В.І. Гладких, А.Е. Городецького, Е.А. Іванова, А.Б. Мельникова, А.Г. Наговіцина, Ю.Я. Ольсевіч.

Метою статті $\epsilon$ уточнення теоретичних положень, які розкривають особливості тіньової економіки в Україні в умовах кризи і нестабільності.

Постановка завдання. Зазначена мета визначає постановку й вирішення таких завдань:

- оцінити масштаби тіньової економіки в світі, а також ефективності практики протидії тіньовому сектору української економіки в контексті забезпечення економічної безпеки; 
- дослідити основні аспекти тіньового сектора, які найбільш негативно впливають на функціонування економіки;

- сформувати концептуальні засади державної протидії тіньової економічної діяльності суб'єктів малого та середнього бізнесу в Україні.

Виклад основного матеріалу. Проблема тіньових економічних відносин $\epsilon$ однією з найгостріших для національного господарства. Протягом останніх десятиліть в Україні вони характеризуються економічним зростанням і поліпшенням соціальноекономічного стану населення. Тому увага до тіньової економічної діяльності дещо знизилася. Але у зв'язку з цим є негативний вплив означеного сегмента економіки на національне господарство в досить великих розмірах.

Розглянемо взаємовідносини «держава - тіньова економіка» (рис. 1).

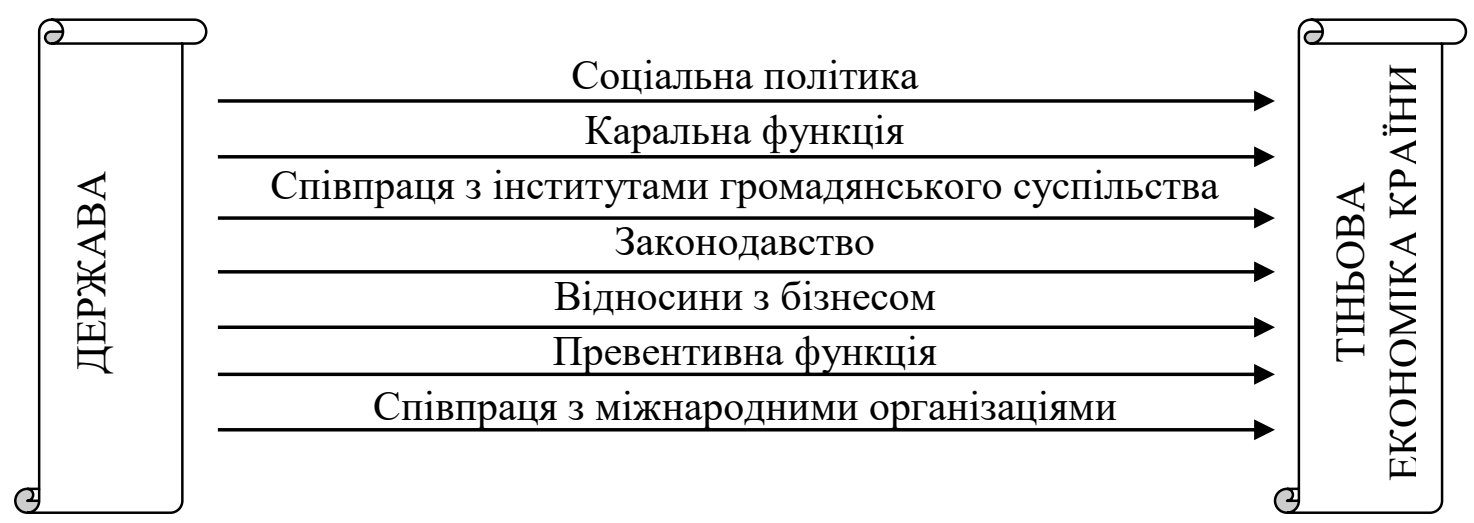

Рисунок 1. Принципи взаємовідносин «держава - тіньова економіка»

Figure 1. Principles of relations "state - the undergorund economy"

Тіньові відносини руйнівним чином відображаються на процесах виробництва й перерозподілу економіко-фінансових ресурсів, зменшують доходну частину бюджетів, $\epsilon$ загрозою національній безпеці. Тіньова економіка характеризується не тільки виведенням з обороту великої кількості ресурсів, але й навмисною зміною статистичних, фінансових, податкових даних звітності, зниженням рівня відкритості економіки. Абстрактні з офіційного обороту ресурси, в разі їх легалізації, можуть стати потужним резервом для економічного зростання [5]. Визнання важливості боротьби зі зростанням тіньової економіки підтверджується й на державному рівні.

Українські та західні вчені-економісти звертають увагу на компенсаційні функції тіньової економіки. Ця функція пом'якшує наслідки помилкових дій державної влади знижує рівень незайнятості робочої сили країни, поставляє на ринок товарів і послуг дешеву продукцію для покупців з низьким рівнем доходів. Однак як показує практика в процесі економічного зростання або в момент подолання соціальних криз підвищується значення деструктивної функції тіньового сектора, а компенсаційний вплив стає непомітним. Таким чином, розроблення комплексу заходів з боку держави в боротьбі 3 тіньовим сектором національної економіки є актуальною проблемою. На сьогодні не розроблено комплексного підходу для усунення всіх наявних наслідків функціонування тіньового сектора. Існують ефективні способи боротьби лише з окремими проявами даного сегмента. При цьому вони не враховують ні регіональних, ні національних особливостей. Зменшення обсягу тіньового обороту є першочерговим завданням, що стоїть перед державною політикою будь-якої країни, але все ж необхідно ретельно підбирати засоби його зниження. 
Підвищення адміністративного навантаження на сферу, створення нових i розширення вже наявних контролюючих органів фінансово-господарської сфери на державному рівні призводять до уповільнення процесу економічного зростання. Необхідно вибірково вживати заходи регулювання діяльності суб'єктів господарювання, основну роль у процесі якого відіграє індикативна функція тіньового сектора. Основною метою іiі $є$ демонстрація недоліків вже існуючих механізмів державного регулювання економічної сфери.

Для вирішення зазначених проблем необхідно з усіх аспектів проаналізувати взаємний вплив тіньової та офіційної економіки, в тому числі на всі сфери суспільного життя, розробити методики оцінювання масштабності тіньового сегмента по всіх видах економічної діяльності, ефективні способи перенесення економічних і фінансових ресурсів у легальну економіку. Комплексний підхід до розроблення науково обгрунтованих заходів економічного та адміністративного характеру в кінцевому підсумку призведе до зменшення частки тіньового сектора в національній економіці й сприятиме ії стабільному розвиткові.

Основними передумовами, що зумовлюють розвиток тіньової діяльності на національному рівні, по праву можна визнати наявність прогалин i колізій у господарському законодавстві, викликану недосконалістю нормативно-правової бази, слабкий розвиток фінансових інститутів з контролюючими функціями, недосконалість правової бази в сфері податків, низький рівень заробітної плати у значної частини населення, що змушує їх шукати додаткові джерела доходу. Особливе місце серед перерахованих вище явищ займає результат злиття кримінальної та економічної злочинності - кримінальна діяльність, відрізняється на сучасному етапі розвитку економічних відносин організованістю і професіоналізмом суб'єктів, що здійснюють правопорушення і злочини, високим рівнем технічного шахрайства 3 використанням комп'ютера й глобальної мережі Інтернет, а також корумпованою залежністю організованої злочинності з державними службовцями [3].

Для здійснення ефективної боротьби з тіньовим сектором російської економіки одного визнання наявності цієї проблеми недостатньо.

Необхідно на найвищому державному рівні усвідомлення як найважливішого політичного завдання неминучості усунення цієї ключової перешкоди для забезпечення підвищення ефективності економічних показників національної економіки. При цьому необхідно враховувати ті глибинні процеси, які відбуваються під впливом тіньового бізнесу. До числа найважливіших з них, наприклад, відносяться: збільшення обсягу нелегального (офіційно не враховується) грошового обороту, в тому числі легалізації незаконних і злочинних доходів, відтоку тіньових фінансових ресурсів з української економіки i, як наслідок, їх використання для розвитку та підвищення конкурентоспроможності іноземних економік; зростання злочинності в сфері економічної діяльності, корумпованості політичної влади й недовіри до неї.

Міцна присутність в економіці цих елементів руйнівним чином здатна впливати не тільки на фінансову та соціально-економічну систему країни, й на суспільнополітичну стабільність і світовий імідж української держави. 3 огляду на всю складність проблеми для іiі ефективного вирішення слід вживати заходи, які повинні носити комплексний характер і мати надійний, невідворотний механізм, що забезпечує їх ефективність.

У зв’язку з цим у рамках Державної стратегії економічної безпеки України повинна бути розроблена й реалізована в максимально стислі терміни комплексна програма щодо попередження та запобігання легалізації в офіційній економіці незаконних (тіньових) доходів, охоплюючи заходи з удосконалення податкової системи, запобігання відтоку капіталу за кордон і скорочення масштабів корупції [1]. 
Основним завданням, що стоїть перед державним регулюванням тіньової економіки, $є$ визначення іiі граничного значення в рамках національної економіки, зокрема для економіки України. У зв'язку з цим необхідно враховувати обставину, що повністю викорінити це явище неможливо.

Мінімальний рівень тіньової економіки повинен знаходиться в межах показника частки тіньової економіки в розвинених країнах - від 8 до 13\% від валового внутрішнього продукту.

Існує ряд обставин, які дозволяють державі робити рішучі дії для скорочення тіньового сегмента. Перше полягає в тому, що завдання щодо зменшення рівня тіньової економіки покладається на державні органи і $є$ для них дуже складним, так як вони не мотивовані іï вирішувати. Друге зумовлено тим, що вирішувати проблему необхідно в усіх суб'єктах одночасно - політика посилення в окремих регіонах призводить до переходу тіньової діяльності в інший суб'єкт, де немає жорстких обмежень [7].

Механізм регулювання тіньового сегмента на державному рівні має носити, як ми вже відзначали вище, комплексний характер державної політики, розрахованої на тривалий період. Це особливо актуально в даний час. Нині в Україні відбувається формування нової політичної обстановки й підвищується роль та відповідальність держави перед громадянами України в сфері економіки [8].

У процесі розроблення державного механізму протидії тіньовій діяльності необхідно враховувати, що на макроекономічному рівні тіньові відносини аналізуються 3 позицій впливу на структуру економіки, виробництва, розподілу, перерозподілу й споживання валового внутрішнього продукту (ВВП), на зайнятість, інфляцію, економічне зростання та інші макроекономічні процеси. А на мікроекономічному рівні необхідно сконцентруватися на вивченні економічної поведінки й прийняття рішень суб'єктами тіньової економіки, підприємствами, дослідженні окремих нелегальних ринків товарів і послуг, цінних паперів.

Існує три підходи до формування механізму протидії держави тіньовій економіці:

- організаційний підхід;

- управлінський підхід:

- організаційно-управлінський підхід [2].

Організаційний підхід дозволяє відстежувати дію об'єктивних закономірностей організації, розкривати критерії та принципи організованості, досліджувати організаційну основу процесу протидії тіньовій економіці, організаційну сферу й умови активності суб'єктів підприємницької діяльності, аналізувати організаційний механізм і прогнозувати шляхи його вдосконалення [6].

Управлінський підхід вивчає управління як одну з функцій організації, розробляє мету, можливості й методи управлінського впливу на організацію протидії тіньовій економіці відповідно до об’єктивних закономірностей управління.

Організаційно-управлінський підхід у формуванні механізму протидії тіньовій економіці включає системний аналіз поведінки суб'єктів у тіньовому секторі економіки, його формалізацію, дослідження функцій i, відповідно, виявлення закономірностей протидії офіційній економіці як системі. Він логічно вимагає побудови державної системи протидії тіньовій економіці, одним з елементів якої і є механізм протидії тіньовій економіці, зокрема його організаційно-управлінської складової.

В рамках вивчення останнього підходу необхідно звернути увагу на дослідження C.M. Проява в боротьбі з корупцією, в якому розроблена загальна модель формування й функціонування організаційно-управлінської системи боротьби з нею [4].

До суб'єктів, які здійснюють державну протидію тіньовій економіці, відносяться:

- носії господарських інтересів - соціальні групи, до яких відносяться малозабезпечені верстви населення: пенсіонери, інваліди, студенти та ін.; 
- виразники господарських інтересів - громадські організації, що представляють і захищають інтереси профспілки, союзів підприємців, фермерів, торговців, студентів та ін.;

- виконавці господарських інтересів - ієрархічна система державних органів виконавчої влади.

Висновки. У зв'язку з цим об'єктами регулювання з боку державних органів виступають сфери й галузі соціально-економічного життя. Найчастіше на державному рівні виступає сектор тіньової економіки на національному та регіональному рівнях.

Виконані дослідження, систематизація теоретичних підходів дозволили якісно досліджувати більшу частину проблем і розробити широкий спектр обгрунтованих практичних пропозицій, які очікують наукового обговорення й упровадження. Встановлено, що під час розрізненості досліджень тіньової економіки, які недостатні для необхідної комплексності, без якої вирішення проблем формування систем протидії тіньовій економіці неможливе.

3 урахуванням необхідності зниження негативного впливу тіньового сектора на функціонування економіки і на підставі численних досліджень конкурентної боротьби сформовані пропозиції щодо формування регіональних професійних співтовариств у сфері забезпечення фінансової безпеки, здатних розширювати спільну практику застосування актуальних механізмів у сфері безпеки.

Conclusions. In this connection from the side of public organs spheres and industries of socio-economic life come forward adjusting objects. More frequent all at state level the sector of shadow economy comes forward at national and regional level.

The executed researches, systematization of theoretical approaches, allowed highquality to probe greater part of problems and develop the wide spectrum of the grounded practical suggestions which expect a scientific discussion and introduction. It is set that under time separateness of researches of shadow economy, which not enough necessary complexity without which decision of problems of forming of the systems of counteraction a shadow economy it is impossible.

Taking into account the necessity of decline of negative influence of shadow sector on functioning of economy and on the basis of numerous researches of competitive activity, formed suggestions in relation to forming of regional professional concords in the field of providing of financial safety, able to extend general practice of application of actual mechanisms in the field of safety.

\section{Використана література}

1. Бобырев, В.В. О воздействии государства на теневую экономику: принципы анализа, направления работы [Текст] / В.В. Бобырев // Менеджмент и бизнес-администрирование. - 2009. - № 3. - С. $32-55$.

2. Верещагин, С.Г. Политика государства по борьбе с теневой экономикой, уклонением от уплаты налогов и противодействию легализации «грязных денег» [Текст] / С.Г. Верещагин // Бизнес в законе. -2006 . - № $3-4$. - С. $38-55$.

3. Лунёв, Д.С. Система мер по предотвращению и снижению уровня воздействия теневой экономики на деятельность и развитие организаций в регионе [Текст] / Д.С. Лунёв, Р.С. Лунёв // Криминологический журнал Байкальского государственного университета экономики и права. 2013. - № 2. - С. $62-73$.

4. Проява, С.М. Экономизация коррупции. Механизм противодействия: монографія. [Текст] / С.М. Проява. - М. : ЮНИТИДАНА: Закон и право, 2008.

5. Радюкова, Я.Ю. Экономическая безопасность страны как многоуровневая система элементов и отношений [Текст] / Я.Ю. Радюкова, И.Н. Шамаев // Социально-экономические явления и процессы. - Тамбов, 2011. - Вып. 1 - 2. - С. $194-198$.

6. Самаруха, В.И.Теневая экономика в системе предпринимательской деятельности региона. [Текст]/ В.И. Самаруха, В.И. Буров. - Иркутск : Изд-во БГУЭП, 2010. 
7. Федорова, А.Ю. Становление и развитие системы межбюджетных отношений в Российской Федерации [Текст] / А.Ю. Федорова, С.С. Самойлова, Н.И. Дорожкина // Социально-экономические явления и процессы. - Тамбов, 2013. - № 5 (051). - С. $210-215$.

8. Шепелев, О.М. Государство и корпоративное управление в российской экономике [Текст] / О.М. Шепелев, В.Ю. Сутягин // Актуальные инновационные исследования: наука и практика. 2010. - № 2. - C. 23.

\title{
Referenses
}

1. Bobyrev V. V. (2009) O vozdeistvyy hosudarstva na tenevuiu эkonomyku: pryntsypy analyza, napravlenyia raboty [About affecting of the state shadow economy: principles of analysis, work assignment] Menedzhment y byznes-admynystryrovanye. no. 3, pp. $32-55$.

2. Vereshchahyn S. H. (2006) Polytyka hosudarstva po borbe s tenevoi ekonomykoi, uklonenyem ot uplaty nalohov y protyvodeistvyiu lehalyzatsyy «hriaznykh deneh» [Politics of the state on a fight against a shadow economy, avoiding tax payment and to counteraction of legalization of "dirty money"] Byznes $\mathrm{v}$ zakone, no 3-4, pp. $38-55$.

3. Lunev D. S., Lunev R. S. (2013) Systema mer po predotvrashchenyiu y snyzhenyiu urovnia vozdeistvyia tenevoi ekonomyky na deiatelnost y razvytye orhanyzatsyi $v$ rehyone [System of measures on prevention and decline of level of influence of shadow economy on activity and development of organizations in a region] Krymynolohycheskyi zhurnal Baikalskoho hosudarstvennoho unyversyteta ekonomyky y prava, no. 2, pp. $62-73$.

4. Proiava S. M. (2008) Ekonomyzatsyia korruptsyy. Mekhanyzm protivodeistvyia: monohrafyia. [Economy of corruption. Mechanism of counteraction] Moskva: YuNYTYDANA (in Rossian).

5. Radiukova Ya. Yu., Shamaev Y. N. (2011) Ekonomycheskaia bezopasnost strany kak mnohourovnevaia systema elementov y otnoshenyi [Economic security of country as multilevel system of elements and relations] Sotsyalno-ekonomycheskye yavlenyia y protsesu, vol. 1-2, pp. $194-198$.

6. Samarukha V. Y., Burov V. Y. (2010) Tenevaia ekonomyka v systeme predprynymatelskoi deiatelnosty rehyona [A shadow economy is in the system of entrepreneurial activity of region] Yrkutsk, (in Rossian)

7. Fedorova A. Yu., Samoilova S. S., Dorozhkyna N. Y. (2013) Stanovlenye y razvytye systemy mezhbiudzhetnykh otnoshenyi $\mathrm{v}$ Rossyiskoi Federatsyy [Becoming and development of the system of interbudgetary relations is in Russian Federation] Sotsyalno-ekonomycheskye yavlenyia y protsessu, no. 5 , pp. $210-215$.

8. Shepelev O. M., Sutiahyn V. Yu. (2010) Hosudarstvo y korporatyvnoe upravlenye v rossyiskoi ekonomyke [The state and corporate management are in the Russian economy] Aktualnue ynnovatsyonnue yssledovanyia: nauka y praktyka, no 2, pp. 23.

Отримано 12.09.2017

\section{УДК 351.824}

Ірина СТРУТИНСЬКА

\author{
Тернопільський національний технічний університет \\ імені Івана Пулюя, Тернопіль, Україна
}

\section{ТРАНСФОРМАЦІЯ РЕГІОНАЛЬНОГО УПРАВЛІННЯ НА ОСНОВІ АНАЛІЗУ ТА ІНТЕГРАЦІЇ ДАНИХ $З$ МЕТОЮ ЗАСТОСУВАННЯ ПРОЕКТНОГО ПІДХОДУ}

\footnotetext{
Резюме. Проведено дослідження та аналіз даних щุодо пройдених кроків об’єднаними територіальними громадами на шляху реалізації сучасної моделі децентралізачії. Здійснено аналіз розподілу субвениії з державного бюджету місиевим бюджетам на формування інфраструктури об'єднаних територіальних громад. Визначено основні проблеми, з якими зустрічаються новостворені
} 